\title{
Identifying Rates of Meadowfoam (Limnanthes alba) Seed Meal Needed for Suppression of Meloidogyne hapla and Pythium irregulare in Soil
}

Yurdagül Şimşek Erşahin, Çankırı Karatekin University, Çankırı, Turkey 18200; Jerry E. Weiland and Inga A. Zasada, United States Department of Agriculture-Agricultural Research Services, Horticultural Crops Research Laboratory, Corvallis, OR 97330; and Ralph L. Reed and J. Fred Stevens, Department of Pharmaceutical Sciences, Oregon State University, Corvallis 97331

\begin{abstract}
Şimşek Erşahin, Y., Weiland, J. E., Zasada, I. A., Reed, R. L., and Stevens, J. F. 2014. Identifying rates of meadowfoam (Limnanthes alba) seed meal needed for suppression of Meloidogyne hapla and Pythium irregulare in soil. Plant Dis. 98:1253-1260.

Meadowfoam (Limnanthes alba) is a commercial oilseed annual crop grown in Oregon. After extracting oil from seed, the remaining seed meal is rich in the secondary plant metabolite glucolimnanthin, which can be converted into pesticidal compounds such as 3-methoxybenzyl isothiocyanate (ITC) and 3-methoxyphenylacetonitrile (nitrile) in the presence of the enzyme myrosinase. In previous studies, we demonstrated that ITC and nitrile, produced by mixing freshly ground meadowfoam seed with meadowfoam seed meal, are toxic to the plantparasitic nematode Meloidogyne hapla and the plant pathogen Pythium irregulare. In this study, we evaluated factors that might influence the implementation of meadowfoam seed meal into agricultural production systems for soilborne pathogen and nematode control. Rate-finding experiments demonstrated that a minimum $1.0 \%$ seed/seed meal formulation (wt/wt) was necessary to achieve nematode and pathogen suppression; seed meal alone was insufficient for complete control of $M$. hapla and stimulated the growth of P. irregulare. When this $1.0 \%$ seed/seed meal formulation was used, a greater soil amendment rate

was required to cause $100 \%$ mortality of $P$. irregulare $(1.0 \% \mathrm{wt} / \mathrm{wt})$ than for $M$. hapla $(0.5 \% \mathrm{wt} / \mathrm{wt})$. In phytotoxicity experiments, soil amended with the $1.0 \%$ seed/seed meal formulation was consistently phytotoxic to wheat, cucumber, and tomato. However, phytotoxic effects were mitigated by a delayed planting into the amended soil. A final assay to monitor concentrations of ITC and nitrile in conjunction with assessing $M$. hapla and $P$. irregulare mortality was conducted over a 6-day period in soils amended at 0.5 and $1.0 \%$ (wt/wt) with the $1.0 \% \mathrm{seed} / \mathrm{seed}$ meal formulation. The response was rapid, with $100 \%$ mortality of both organisms within $2 \mathrm{~h}$ after exposure to amended soil. Concentrations of nitrile remained relatively constant over the 6-day period (approximately 0.017 and $0.032 \mathrm{mg} / \mathrm{ml}$ at 0.5 and $1.0 \%$ amendment rates, respectively), whereas ITC production increased rapidly and peaked 12 to $24 \mathrm{~h}$ after amendment $(0.083$ and $0.171 \mathrm{mg} / \mathrm{ml}$ at 0.5 and $1.0 \%$ amendment rates, respectively) before returning to near undetectable levels.
\end{abstract}

Concerns about the sustainability of traditional agricultural pest management practices and the continued growth in organic farming have led to increased interest in the development of alternative means to control diseases caused by soilborne pathogens and plantparasitic nematodes. Interest is further driven by the lack of effective nematicidal products. Within this context, plant secondary metabolites such as phytoalexins and allelochemicals have received a great deal of attention for their potential to suppress disease-causing organisms $(6,21)$. One such group of compounds that has been extensively evaluated within the pest management research community is the glucosinolates. Glucosinolates are naturally occurring secondary plant metabolites that have mostly been characterized from plants within the orders Capparales and Brassicales (8).

Meadowfoam (Limnanthes alba Hartw. ex Benth.) is a member of the order Brassicales and has been grown as a commercial oilseed annual crop in the Willamette Valley of Oregon since the 1980s. This crop plays an important role as a winter rotation crop in grass seed production systems. After harvest, the seed is pressed to yield oil containing unique long-chain fatty acids of high quality and commercial value in cosmetics and lubricants, making meadowfoam a high-value oilseed crop (18). After the oil has been extracted from the seed, the remaining seed meal contains the glucosinolate glucolimnanthin and 3-methoxyphenylacetonitrile, a heatinduced degradation product of glucolimnanthin produced during the oil extraction process $(8,27)$. When plant cells containing glucolimnanthin are physically damaged and exposed to moisture and

Corresponding author: J. E. Weiland, E-mail: Jerry.Weiland@ ars.usda.gov

Accepted for publication 26 March 2014.

http://dx.doi.org/10.1094/PDIS-09-13-0967-RE

(C) 2014 The American Phytopathological Society the enzyme myrosinase, this secondary plant metabolite degrades into toxic breakdown products, including 3-methoxybenzyl isothiocyanate (ITC), 3-methoxyphenyl ethanethioamide (thioamide), 2(3-methoxyphenyl)-acetamide (acetamide), and additional 3-methoxyphenylacetonitrile (nitrile) (27). In a previous study (33), we demonstrated the toxicity of the glucolimnanthin degradation products nitrile, thioamide, and ITC to the plant-parasitic nematode Meloidogyne hapla Chitwood and the plant pathogen Pythium irregulare Buisman. The ITC was the most toxic to both organisms while glucolimnanthin and its degradation product acetamide were not toxic to either organism. This research demonstrated the potential to utilize meadowfoam seed meal (MSM) as a soil amendment to manage these soilborne pathogens.

Many different glucosinolate-containing plants and seed meals have previously been evaluated and proven effective for the suppression of weeds, soilborne pathogens, and plant-parasitic nematodes $(4,5,15,19-21)$. In fact, Stevens et al. (27) demonstrated that MSM was herbicidal and, when amended to soil, reduced the germination of Bromus tectorum. However, it was necessary to combine MSM with meadowfoam seed (MS) to achieve weed suppression. Increased activity with the addition of MS to MSM is due to the fact that the MSM remaining after oil extraction no longer contains the enzyme myrosinase needed to convert glucolimnanthin to pesticidal compounds $(27,33)$. This is easily overcome by adding unprocessed, ground MS, which contains myrosinase, to the MSM to initiate the chemical reaction.

The overarching goal of this research was to generate information to facilitate the implementation of MSM into crop production systems for plant-parasitic nematode and soilborne pathogen management. As in our previous study (33), we chose to continue to focus on the economically important plant-parasitic nematode $M$. hapla and plant pathogen $P$. irregulare. M. hapla can negatively impact the yield of a variety of crops (10), while P. irregulare is an economically important pathogen of over 200 host plant species, 
including cereals and grasses, vegetables, fruit and nut crops, forest tree seedlings, and a number of floricultural crops $(9,31)$. The objectives of this study were to (i) determine the necessity of adding MS to MSM to achieve $M$. hapla and $P$. irregulare suppression; (ii) identify effective amendment rates of MSM+MS that suppress $M$. hapla and P. irregulare in soil; (iii) determine whether effective rates are phytotoxic to tomato, cucumber, and wheat, and; (iv) measure the generation of glucolimnanthin degradation compounds in MSM+MS-amended soil and determine the relationship between compound production and soilborne pathogen suppression.

\section{Materials and Methods}

MSM and MS sources. MSM and MS were provided by Natural Plant Products, Inc. Both were stored at $20^{\circ} \mathrm{C}$ in the dark for the duration of the experiment. MSM was produced in 2010 and MS was harvested in 2010 and 2011. Preliminary tests indicated no effect of MSM or MS collection dates (e.g., 2010 versus 2011 seed batch) on subsequent activity against $M$. hapla or P. irregulare or in causing phytotoxicity to tomato, cucumber, and wheat (data not shown).

Inoculum. M. hapla was originally isolated from a grape (Vitis vinifera L.) vineyard near Veneta, OR and cultured on greenhousegrown tomato (Solanum lycopersicon L.) 'Rutgers'. This population was used in all assays and was the same population used in previous research (33). To obtain inoculum, individual egg masses were picked from roots into water. To obtain second-stage juveniles (J2), egg masses were then placed on a Baermann funnel to hatch; 7 to 10 days later, $\mathrm{J} 2$ were collected, stored at $4^{\circ} \mathrm{C}$, and used within $24 \mathrm{~h}$.

P. irregulare isolate PR155d, originally isolated from a forest nursery field soil (30) and used in the previous study (33), was used to produce inoculum according to methods modified from Weiland et al. (31). Briefly, colonized agar was used to infest fungal spawn bags (Fungi Perfecti) containing 1.25 liter of dilute, clarified V8 juice and 3 liters of coarse vermiculite that had been autoclaved three times for $1 \mathrm{~h}$ at 48 -h intervals. Spawn bags were then incubated in the dark at $20^{\circ} \mathrm{C}$ with weekly mixing by hand. After 30 days, inoculum was removed from the bags, air dried for 3 days, then stored in resealable polyethylene bags at $20^{\circ} \mathrm{C}$ until use.

MSM+MS nematode and pathogen toxicity assays. Soil (1:1 vol/vol washed sand and Willamette loam) that had been steam pasteurized for $3 \mathrm{~h}$, dried for $24 \mathrm{~h}$ at $70^{\circ} \mathrm{C}$, and then passed through a 2-mm-diameter sieve was amended with one of 12 different MSM+MS formulations; a nonamended control was included as an additional, 13th treatment. For each formulation, MS was first ground with an electric coffee grinder (Proctor Silex E160BY; Hamilton Beach Appliances) for approximately $1 \mathrm{~min}$, then mixed by hand with MSM at $0,1.0,2.0$, or $3.0 \%$ (dry wt/wt) in 12 separate resealable plastic bags. Each MSM+MS formulation was then incorporated into $300 \mathrm{~g}$ of soil at $0.5,1.0$, or $2.0 \%$ (dry wt/wt) using an 8-liter, stainless-steel, twin-shell blender (PattersonKelley) for 10 min to yield 12 MSM+MS soil amendment treatments. Soil that was not amended with either MSM or MS was also prepared. For convenience, these treatments will be abbreviated throughout this manuscript as soil amendment rate/seed formulation MSM+MS. For example, soil amended at $2.0 \%$ with the $3.0 \%$ MSM+MS formulation would be abbreviated as $(2.0 / 3.0$ MSM+MS). Finally, soil for each of the 13 treatments was then moistened with nonsterile distilled water $(0.12 \mathrm{ml} / \mathrm{g}$ of dry soil $)$ and infested immediately with each organism as described below.

For M. hapla, $56 \mathrm{~g}$ of moistened soil of each treatment was added to 10-by-10-cm resealable plastic bags and approximately $1,000 \mathrm{M}$. hapla $\mathrm{J} 2 \mathrm{~s}$ were added in $2 \mathrm{ml}$ of water to each bag. Bags were closed, gently massaged to distribute nematodes, then opened to allow air circulation. For $P$. irregulare, infested vermiculite inoculum was added to moistened soil in resealable plastic bags to achieve 100 propagules/g (ppg) of moist soil and then mixed by hand. Infested soil treatments were then distributed into polyethylene $50-\mathrm{ml}$ tubes (56 g/tube) and $2 \mathrm{ml}$ of nonsterile distilled water was added to the soil surface. Tubes were left uncapped to allow air circulation. Bags ( $M$. hapla $)$ and tubes ( $P$. irregulare) were then incubated at $20^{\circ} \mathrm{C}$ in the dark for 4 days. The soil surface was monitored daily and approximately 1 to $2 \mathrm{ml}$ of nonsterile distilled water was added as necessary to remoisten the soil surface. Individual tubes and bags were arranged according to a completely randomized design (CRD), with five replicate tubes or bags for each treatment-pathogen combination; these assays were conducted twice.

At the end of the assay, M. hapla nematodes were quantified by placing the contents of the bags onto tissue paper supported by a screen, and the screen was placed onto a Baermann funnel for 5 days (13). Nematodes were collected from Baermann funnels and stored at $4^{\circ} \mathrm{C}$ until counted at $\times 40$ using a dissecting microscope. Mortality of $P$. irregulare was evaluated with two concurrent methods used previously $(30,32)$ : by dilution plating onto a semiselective medium (PARP) for Pythiaceous species (14) to quantify soil populations and by baiting the remaining soil with rhododendron leaf disks to confirm mortality. For the plating method, soil was placed into separate $10-$ by- $10-\mathrm{cm}$ resealable plastic bags and mixed thoroughly. A 10-g subsample was removed and mixed with $90 \mathrm{ml}$ of $0.2 \%$ water agar in a $250-\mathrm{ml}$ Erlenmeyer flask on a rotary shaker set at $300 \mathrm{rpm}$ for $30 \mathrm{~min}$. A $500-\mu \mathrm{l}$ aliquot of the suspension was then spread with a sterile glass rod on each of five petri plates containing $20 \mathrm{ml}$ of PARP agar. Plates were incubated for 2 days in the dark at $20^{\circ} \mathrm{C}$ before washing off the soil under running tap water and counting the number of $P$. irregulare colonies. For the baiting method, the remaining soil in each bag (approximately $45 \mathrm{~g}$ ) was placed into a 150-ml wax paper cup and baited with five 5-mm-diameter freshly collected, field-grown Rhododendron 'Unique' leaf disks from leaves that were approximately 4 months old, according to the double-cup leaf disk baiting method (16). After 2 days of incubation in the dark at $20^{\circ} \mathrm{C}$, the leaf disks were removed, blotted dry, and plated on PARP agar medium to evaluate for the presence or absence of $P$. irregulare colonies after two further days of incubation in the dark at $20^{\circ} \mathrm{C}(30,32)$.

MSM+MS phytotoxicity assay. The same MSM+MS and control treatments used in the nematode and pathogen toxicity assays were also evaluated for their potential phytotoxic effects on three agronomic plant hosts. Approximately $400 \mathrm{~g}$ of dry amended or nonamended soil (prepared as above) was distributed into five replicate $9-\mathrm{cm}^{2}$ pots for each host and planted immediately. Ten seeds of cucumber (Cucumis sativus L.) 'Straight Eight' or winter red wheat (Triticum aestivum L.), or a single 18- to 25-day-old seedling of Rutgers tomato washed free of soilless media (Sun Grow Horticulture), were then planted into each replicate pot. The pots were watered to field capacity and placed on a greenhouse bench in a randomized complete block design (RCBD). Each MSM+MS and control treatment-plant species combination was replicated five times. The greenhouse was maintained at 23 and $18^{\circ} \mathrm{C}$ (day and night, respectively) for 2 weeks and supplemental light was provided to achieve a $16-\mathrm{h}$ photoperiod. Plants were monitored daily and watered as necessary to maintain a slightly moist soil surface. At the end of the assay (15 days), observations regarding the number of germinated seed (cucumber and wheat), seedling height (cucumber and wheat), and wilt symptoms (tomato) rated on a scale of 0 (no wilt) to 3 (severe wilt) were recorded. Wilt symptoms were not observed on either wheat or cucumber plants and no effects on height were observed on tomato plants for this assay; therefore, these symptoms were not recorded for those host plants. The entire assay was conducted twice.

MSM+MS time-course phytotoxicity assay. Because of the phytotoxicity observed at the minimum amendment rates needed to kill either M. hapla (0.5/1.0 MSM+MS) or P. irregulare (1.0/1.0 MSM+MS), a time-course assay was established to determine whether the symptoms of phytotoxicity could be alleviated by increasing the amount of time between soil amendment with MSM+MS and the planting date. For each treatment $(0.5 / 1.0$ MSM+MS, 1.0/1.0 MSM+MS, plus a nonamended control) and host (cucumber and tomato), approximately $400 \mathrm{~g}$ of dry amended 
or nonamended soil was distributed into five replicate $9-\mathrm{cm}^{2}$ pots and watered to field capacity; then, assay plants were planted into the soil at 0-, 2-, 4-, 6-, and 8-day intervals after amendment. At each time interval, 10 seeds of Straight Eight cucumber or a single 18- to 25-day old seedling of Rutgers tomato, prepared as above, were planted into each replicate pot. Plants were monitored daily and all pots were watered as necessary to maintain a slightly moist soil surface, regardless of whether a plant was present or not (i.e., regardless of the time interval between MSM+MS amendment and planting date). Pots were arranged on a greenhouse bench in an RCBD with five replicate blocks and maintained under the same greenhouse conditions as described above. Plants were allowed to grow for 2 weeks following each planting interval and then evaluated for the number of germinated seed (cucumber only), seedling height (cucumber and tomato), wilt or chlorosis rated on a 0-to-3 scale (tomato), and stem damage rated as present or absent (tomato). This latter symptom was characterized by a region of chlorotic, mainly hairless, hyperplastic stem tissue that extended for 1 to $2 \mathrm{~cm}$ above the soil line. Symptoms of leaf chlorosis were constrained to the leaf margin and were primarily interveinal; eventually, these regions turned necrotic. Wilt, chlorosis, and stem damage were not observed on cucumber; therefore, these symptoms were not recorded for that plant host. The entire assay was conducted twice.

Assay for glucolimnanthin degradation compounds and pathogen mortality over time in MSM+MS-amended soil. The two minimum amendment rates identified in the nematode and pathogen toxicity assay (above) needed to kill either $M$. hapla (0.5/1.0 MSM+MS) or P. irregulare (1.0/1.0 MSM+MS) were assessed for the presence of glucolimnanthin as well as the production of the glucolimnanthin degradation compounds ITC and nitrile, and the concurrent suppression of $M$. hapla and $P$. irregulare at 10 time intervals after incorporation of MSM+MS into soil $(0,2$, 4, 8, 12, 24, 48, 72, 96, and $144 \mathrm{~h}$ ). Thioamide, a glucolimnanthin degradation product which was also toxic to M. hapla and P. irregulare (33), was not investigated because it is only produced when MSM+MS is further amended with iron (27) and it was less toxic than either ITC or nitrile (33). MSM+MS soil treatments were prepared as described above (0.5/1.0 MSM+MS for M. hapla, 1.0/1.0 MSM+MS for P. irregulare, plus a nonamended control for each organism), moistened with nonsterile distilled water $(0.12$ $\mathrm{ml} / \mathrm{g}$ of dry soil), and infested immediately with each organism. For M. hapla, $56 \mathrm{~g}$ of moistened, amended or nonamended soil was distributed to replicate $50-\mathrm{ml}$ tubes and a $2.5-\mathrm{cm}$-deep hole was made in the center of the soil. Then, approximately 1,000 M. hapla juveniles were added to the hole in $2 \mathrm{ml}$ of water, and the hole was closed. For $P$. irregulare, amended and nonamended soil was infested as described in the pathogen toxicity assay. All tubes were incubated at $20^{\circ} \mathrm{C}$. The contents of each tube were examined daily and remoistened with 1 to $2 \mathrm{ml}$ of nonsterile distilled water if the soil surface appeared dry. Each time interval-MSM+MS treatment (amended or nonamended)-organism combination was replicated three times, and the entire assay was conducted twice.

Chemical and pathogen extractions for time 0 began immediately after inoculation and distribution of soil into the 50-ml tubes and occurred thereafter at the time intervals indicated above. For all of the time intervals except $12 \mathrm{~h}$, chemical extractions of soil were only conducted on amended treatments; at $12 \mathrm{~h}$, a set of three nonamended soil replicates was also extracted as a negative control to confirm the absence of glucolimnanthin and its degradation products. At each extraction time, the contents of each tube were emptied into a 10-by-10-cm resealable plastic bag and mixed thoroughly (for $P$. irregulare) or placed directly on a tissue supported by a screen (for M. hapla). A 5-g aliquot of soil was then removed from the bag or tissue and placed in a clean 50-ml tube, and $15 \mathrm{ml}$ of $94 \%$ methanol was added. The contents were vortexed for $10 \mathrm{~s}$, sonicated for $10 \mathrm{~min}$ (Branson 2510 Ultrasonic Cleaner), then incubated for $1 \mathrm{~h}$ at $20^{\circ} \mathrm{C}$. Each tube was then centrifuged for 5 min at 3,000 rpm and $1 \mathrm{ml}$ of the supernatant was transferred to a 1.5-ml Eppendorf tube before centrifuging for $10 \mathrm{~min}$ at 13,000 rpm. Finally, $900 \mu \mathrm{l}$ of the solution was removed and placed in an 8-by-40-mm glass vial and stored at $-20^{\circ} \mathrm{C}$ until chemical analyses could be conducted (see below). The remaining $45 \mathrm{~g}$ of amended or nonamended soil at each time interval was assayed for $P$. irregulare and M. hapla mortality, as described above.

Standards used in this study included 3-methoxyphenyl acetonitrile (Sigma-Aldrich), 3-methoxybenzyl isothiocyanate (Oakwood Products), and glucolimnanthin, which was extracted from $L$. alba seed meal (Natural Plant Products) and purified as described (27). High-performance liquid chromatography analysis of soil incubation extracts employed a system consisting of a Waters Delta 600 solvent delivery system, a Waters 717 plus autosampler, a Waters 2996 photodiode array detector, a Waters 600 controller, and a data acquisition/processing computer with Empower software (Waters). Separations were achieved using a reverse-phase 4.6-by-250-mm Luna 5- $\mu \mathrm{m} \mathrm{C18}$ column (Phenomenex) eluted with $0.1 \%$ aqueous trifluoroacetic acid (solvent A) and acetonitrile (solvent B). A linear solvent gradient was employed starting from $5 \%$ solvent B in solvent A to $100 \% \mathrm{~B}$ over $24 \mathrm{~min}$ at a flow rate of $1.0 \mathrm{ml} / \mathrm{min}$. Online UV spectra were recorded from 210 to $500 \mathrm{~nm}$ and the 274$\mathrm{nm}$ trace was used for calculation of peak areas for all compounds. Analyte concentrations were determined from calibration curves constructed for each analyte.

Statistical analysis. To evaluate nematode and pathogen mortality, M. hapla data were converted to proportions (number of nematodes per $50 \mathrm{~g}$ of soil), then transformed by the arcsine of the square root to control for heteroscedasticity. Counts of $P$. irregulare from the dilution plates were expressed as propagules per gram on a dry soil weight basis. Data for $M$. hapla and P. irregulare were then analyzed for effects of trial, formulation, soil amendment rate, and interactions using a mixed linear model analysis of variance (ANOVA), with trial as a random factor and formulation and soil amendment rate as fixed factors. Means were separated using Tukey's test $(P=0.05)$. For both phytotoxicity assays, data for the number of germinated seedlings (wheat and cucumber) were converted into proportions (number of germinated seedlings/number of planted seed) for each replicate pot. Germination data were then transformed with the arcsine of the square root to control for heteroscedasticity and analyzed for effects of trial, formulation, soil amendment rate, and interactions (phytotoxicity assay) or trial, day, soil amendment rate, and interactions (time-course phytotoxicity assay) using the same ANOVA model and method for means separation as described above. Nontransformed seedling height data (tomato, wheat, and cucumber) were analyzed in the same manner. Ratings of tomato wilt severity from the phytotoxicity assay were analyzed for effects of trial, MSM+MS treatment, and interaction using a nonparametric approach for ordinal data that uses rank-based methods (22). Similarly, ratings of tomato wilt and chlorosis severity from the time-course phytotoxicity assay were analyzed for effects of trial, soil amendment rate, day, and interaction using the same approach. The frequency of tomato stem damage was analyzed by Fisher's exact test (25). Treatment means were separated using Tukey's test $(P=0.05)$ and with pairwise comparisons using specific contrasts. All analyses were performed with Minitab Statistical Software (release 15; Minitab Inc.) or SAS 9.2 (SAS Institute Inc.).

\section{Results}

MSM+MS nematode and pathogen toxicity assays. The soil population of $M$. hapla in nonamended (negative control) soil averaged $61 \pm 3.0 \%$ (mean \pm standard error). Amendment with MSM alone caused soil populations to decrease, with 57,84 , and $93 \%$ mortality observed at $0.5,1.0$, and $2.0 \%$ MSM soil amendment rates, respectively $(P=0.001)$. However, all MSM+MS treatments, regardless of formulation, resulted in complete $(100 \%)$ mortality, and no living $M$. hapla were recovered from amended soil. No trial effect was observed $(P=0.354)$.

The soil population of $P$. irregulare in nonamended soil averaged $21 \pm 1.5 \mathrm{ppg}$. Amending soil with MSM alone at $0.5,1.0$, or $2.0 \%$ caused soil populations to increase approximately 25 -fold over the 
nonamended population level $(P<0.001)$, regardless of the amendment rate $(555 \pm 75.0,543 \pm 65.9$, and $522 \pm 64.7 \mathrm{ppg}$, respectively). However, once soil was amended with MSM+MS, soil populations decreased to $0 \mathrm{ppg}$ for all but the lowest soil amendment rate and formulation (0.5/1.0 MSM+MS), for which the soil population $(20 \pm 6.9 \mathrm{ppg})$ did not differ from that found in the nonamended soil $(P=0.911)$. Although a trial effect was observed $(P<0.001)$, results were similar when each trial was analyzed separately (data not shown).

MSM+MS phytotoxicity assay. Except for the $2.0 \%$ amendment rate $(P<0.001)$, MSM alone $(0.5$ and $1.0 \%)$ did not cause tomato plants to wilt and yielded results similar to those in the nonamended control ( $P \geq 0.984)$ (Fig. 1A). Wilt symptoms with $2.0 \%$ MSM alone were not immediately apparent and took approximately 1 week to manifest. However, once soil was amended with
MSM+MS, regardless of formulation, tomato plants wilted within a few hours after transplanting into amended soils and therefore were rated higher for wilt symptoms than the nonamended control $(P<0.001)$. Cucumber germination was also unaffected by MSM alone at 0.5 or $1.0 \%(P \geq 0.580)$ but was reduced at the $2.0 \%$ amendment rate $(P<0.001)$ (Fig. 1B). Cucumber germination was similarly unaffected when soils were amended with $0.5 \%$ MSM formulated with MS, regardless of formulation $(P \geq 0.537)$. Only the 1.0 and 2.0 MSM+MS amendment rates, regardless of formulation, reduced cucumber germination compared with the nonamended control $(P \leq 0.035)$; however, increasing rates of MS did not significantly reduce cucumber germination further. When cucumber height was considered (Fig. 1C), the effect of MSM alone or combined with MS was more evident. Only the $0.5 / 0.0$ or 0.5/1.0 MSM+MS treatments were similar to the nonamended
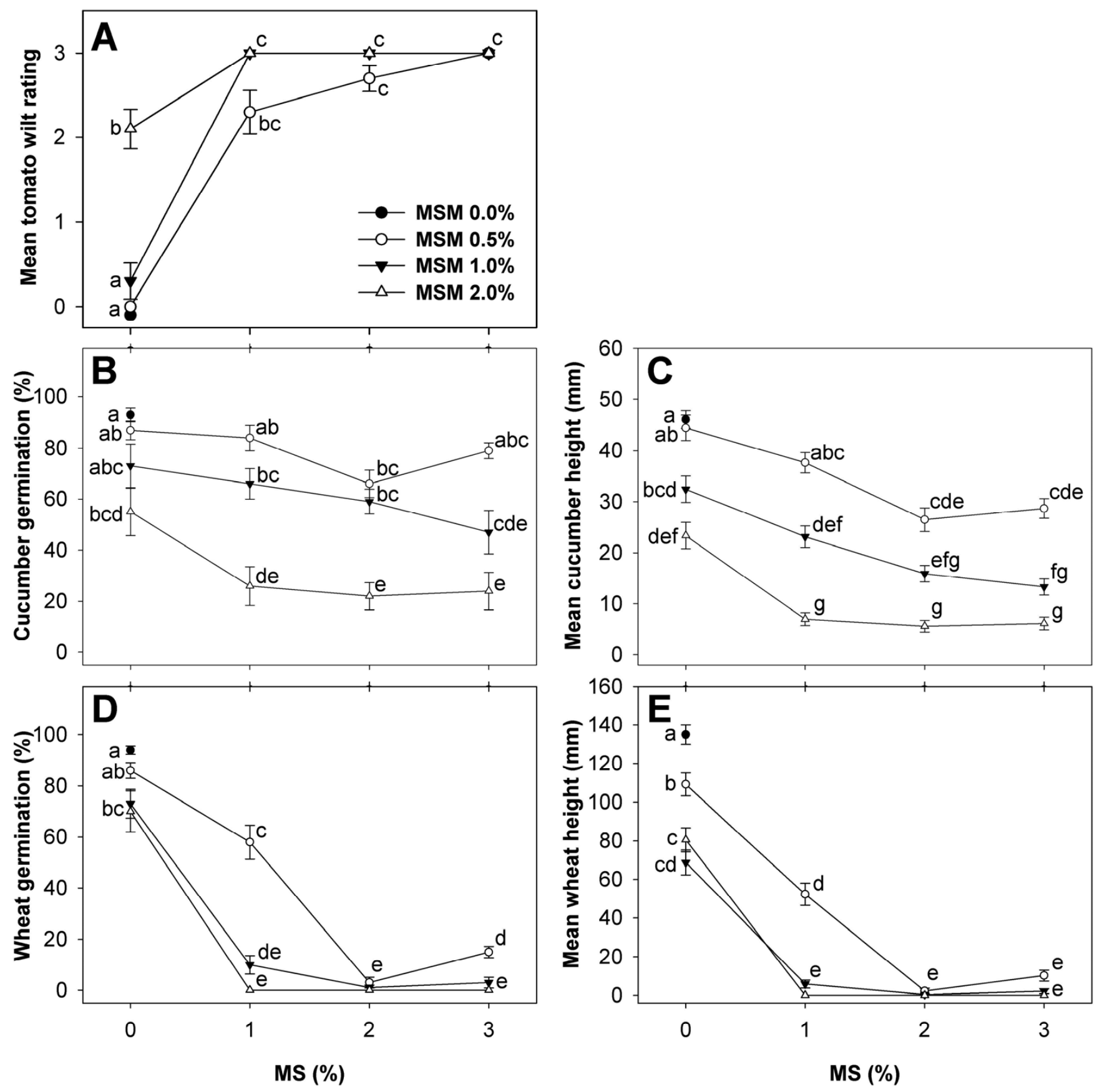

Fig. 1. Responses of $\mathbf{A}$, tomato; $\mathbf{B}$ and $\mathbf{C}$, cucumber; and $\mathbf{D}$ and $\mathbf{E}$, wheat to four soil amendment rates $(0.0$ to $2.0 \%$ wt/wt) of meadowfoam seed meal (MSM) formulated with 0 to $3 \%$ (wt/wt) meadowfoam seed (MS) under ambient greenhouse conditions (23 and $18^{\circ} \mathrm{C}$, day and night, respectively). Wilt symptoms on tomato were rated on a scale of 0 (none) to 3 (severe) from one tomato transplant per pot $(n=10$ replicate pots). Cucumber and wheat seed germination and seedling height were based on 10 seeds/pot $(n=10$ replicate pots). MSM+MS treatment means followed by the same letter are not significantly different according to Tukey's test at $P=0.05$. Error bars indicate standard error. 
control $(P \geq 0.582)$. MSM alone at 1.0 and $2.0 \%$ and all other MSM+MS treatments reduced cucumber height $(P \leq 0.028)$ and, in general, the greater the MSM+MS rate the greater the reduction in cucumber height. Both wheat germination and wheat plant height were more sensitive to MSM+MS than cucumber (Fig. 1D and E). In contrast to cucumber germination, only the wheat seed planted in $0.5 \% \mathrm{MSM}$ alone had a similar germination rate as the nonamended control $(P=0.746$; Fig. 1D). All other treatments, whether formulated with MS or not, reduced wheat germination $(P \leq$ 0.002). A similar trend was observed for wheat height (Fig. 1E). Although a trial effect was observed for all parameters measured $(P \leq 0.010)$ except cucumber germination $(P=0.076)$, results were similar when each trial was analyzed separately (data not shown).

MSM+MS time-course phytotoxicity assay. Tomato plants wilted within $6 \mathrm{~h}$ of planting into soil that had been amended immediately prior to or 2 days before planting, regardless of the MSM+MS rate $(P<0.001)$. When planting was delayed for 4 days or longer after amendment, no wilting was observed, regardless of treatment $(P \geq 0.076$; Fig. $2 \mathrm{~A})$. The next symptom to become apparent on tomato plants was stem damage, which typically manifested within 4 days after planting into amended soil. No stem damage was ever observed on tomato planted in nonamended soil (Fig. 2B). At the lower 0.5/1.0 MSM+MS rate, stem damage occurred on tomato planted in soil amended up to 4 days before planting $(P \leq 0.008)$ but not in those planted 6 or 8 days after amendment $(P>0.999)$. At the higher 1.0/1.0 MSM+MS rate, stem damage was still evident at 8 days postamendment $(P \leq 0.033)$. At harvest, chlorosis was evident on all tomato plants planted into MSM+MS-amended soil, regardless of amendment rate and plant- ing time $(P<0.001)$, except for the $0.5 / 1.0 \mathrm{MSM}+\mathrm{MS}$ rate at 8 days postamendment $(P>0.999)$ (Fig. 2C). Chlorosis was not observed on tomato planted in nonamended soil. Both MSM+MS rates also resulted in a reduction in plant height when tomato plants were transplanted into amended soil at 0 or 2 days postamendment (Fig. 2D). However, if planting was delayed 4 days or longer, height was unaffected by either MSM+MS rate.

For cucumber, MSM+MS rate and the amount of time between soil amendment and planting had little impact on germination (data not shown). Germination in the nonamended control averaged $96 \pm 0.75 \%$, regardless of planting date. At either amendment rate, there was a nonsignificant $(P \geq 0.093)$ reduction in germination, regardless of the amount of time between amendment and planting. The impact of MSM+MS rate and postamendment planting time only became evident when cucumber height was considered (Fig. 3). Initially, there was a slight, nonsignificant decrease in cucumber height, especially at the 1.0/1.0 MSM+MS rate, when cucumber was seeded into soil 0 or 2 days postamendment $(P \geq$ $0.059)$. However, cucumber planted into soil 6 days after amendment with the 1.0/1.0 MSM+MS rate and 8 days after amendment with either the $0.5 / 1.0$ or $1.0 / 1.0 \mathrm{MSM}+\mathrm{MS}$ rate were taller than those planted in the nonamended soil $(P<0.001)$ as well as those planted into soils at 0 or 2 days after amending the soil at either amendment rate $(P<0.001)$. Although a trial effect was observed for all parameters measured $(P \leq 0.020)$, except cucumber height $(P=0.810)$, results were similar when each trial was analyzed separately (data not shown).

Assay for glucolimnanthin degradation compounds and pathogen mortality over time in MSM+MS amended soil. At
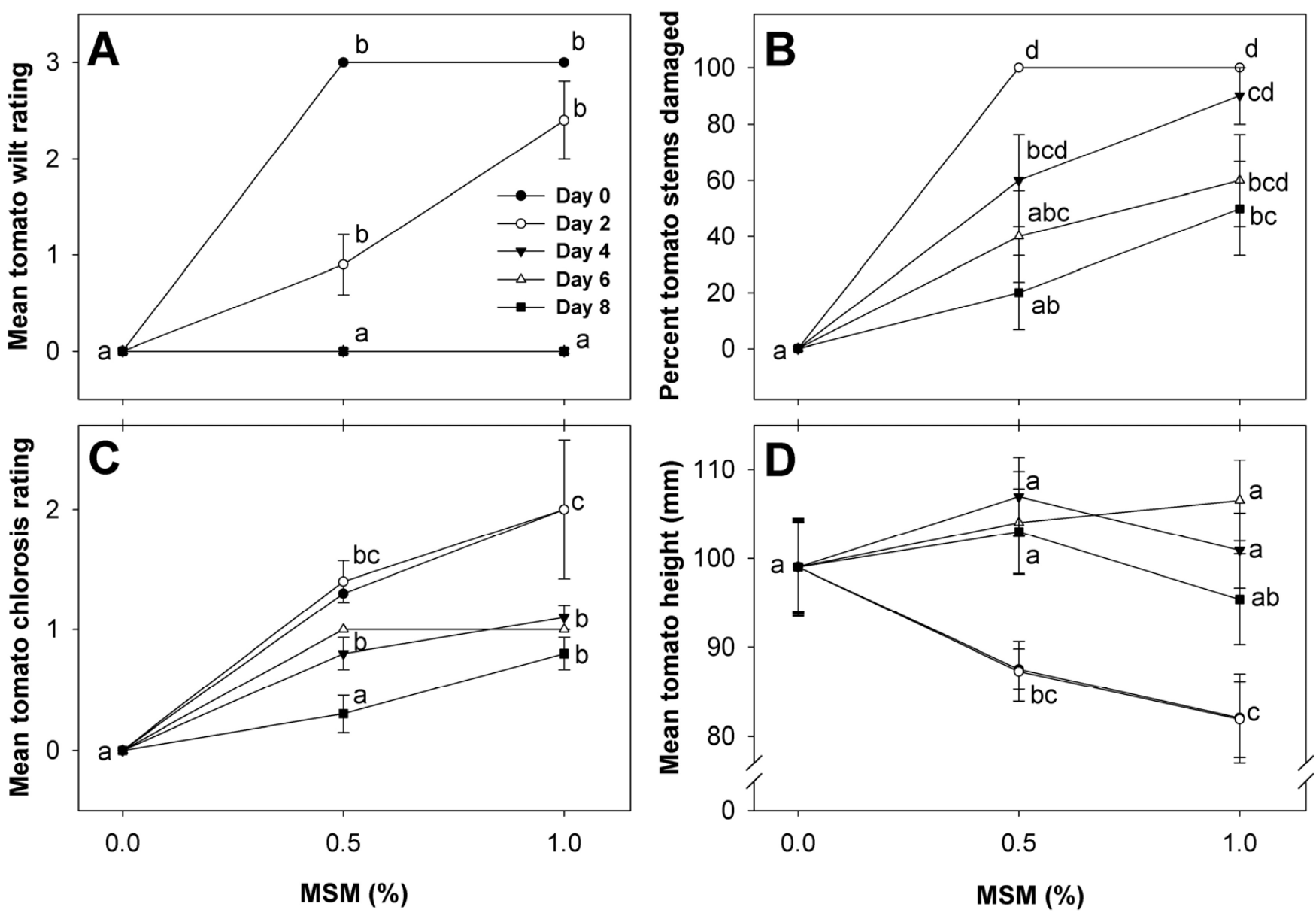

Fig. 2. Responses of tomato transplanted into soil at 0-, 2-, 4-, 6-, and 8-day intervals after amendment with $0.0,0.5$, or 1.0\% (wt/wt) meadowfoam seed meal (MSM) formulated with $1 \%(\mathrm{wt} / \mathrm{wt})$ meadowfoam seed (MS) under ambient greenhouse conditions ( 23 and $18^{\circ} \mathrm{C}$, day and night, respectively). A, Wilt and C, chlorosis symptoms were rated on a scale of 0 (none) to 3 (severe) from one tomato transplant per pot. B, Stem damage was rated as present or absent. Means at $0.0,0.5$, and $1.0 \%$ MSM for $\mathbf{A}$, days 4,6 , and 8 , and $\mathbf{B}$ and $\mathbf{D}$, days 0 and 2 are equal and, therefore, not visible as separate lines or data points; $n=10$ replicate pots. MSM-day treatment means followed by the same letter are not significantly different according to Tukey's test at $P=0.05$. Error bars indicate standard error. 
the low amendment rate (0.5/1.0 MSM+MS), glucolimnanthin decreased from its initial concentration of $0.36 \pm 0.032 \mu \mathrm{mol} / \mathrm{g}$ of soil to nondetectable levels within $24 \mathrm{~h}$ of amendment (Fig. 4A). At the high amendment rate (1.0/1.0 MSM+MS), glucolimnanthin decreased more rapidly from its initial concentration of $0.77 \pm$ $0.036 \mu \mathrm{mol} / \mathrm{g}$ of soil to nondetectable levels by $12 \mathrm{~h}$ postamendment. Nitrile was present throughout the duration of the experiment for both amendment rates $(0.08 \pm 0.002$ and $0.15 \pm 0.002$ $\mu \mathrm{mol} / \mathrm{g}$ of soil for $0.5 / 1.0$ and 1.0/1.0 MSM+MS, respectively), and remained relatively stable before declining on the sixth day. Production of ITC was rapid and peaked at $24 \mathrm{~h}$ with the lower amendment rate $(0.32 \pm 0.024 \mu \mathrm{mol} / \mathrm{g}$ of soil $)$ but peaked earlier at $12 \mathrm{~h}$ for the higher amendment rate $(0.65 \pm 0.040 \mu \mathrm{mol} / \mathrm{g}$ of soil $)$. Thereafter, ITC concentrations rapidly declined to at or near 0 $\mu \mathrm{mol} / \mathrm{g}$ of soil at 6 days. Trial effects were observed for both nitrile and ITC $(P \leq 0.005)$. However, results were similar for each trial separately (data not shown). No trial effect was observed for glucolimnanthin $(P=0.145)$.

M. hapla recovery from nonamended soil averaged $50 \pm 5 \%$ (mean \pm standard error) and $P$. irregulare averaged $163 \pm 5.0 \mathrm{ppg}$, regardless of the time interval in which they were assessed. Within $2 \mathrm{~h}$ after amendment, populations of both M. hapla at the 0.5/1.0 MSM+MS rate and P. irregulare at the 1.0/1.0 MSM+MS rate were dead (data not shown).

\section{Discussion}

To achieve consistent suppression of $M$. hapla and P. irregulare in soil, it was necessary to combine MSM with MS. Similar to our previous study where specific glucolimnanthin degradation products were evaluated against $M$. hapla, $P$. irregulare, and Verticillium dahliae (33), M. hapla was more sensitive to MSM+MS than $P$. irregulare. The effective rate identified for suppression of $M$. hapla was $0.5 / 1.0 \mathrm{MSM}+\mathrm{MS}$ whereas, for $P$. irregulare, it was 1.0/1.0 MSM+MS. The amendment rates found in our study are comparable with those established for brassicaceous amendments Brassica napus, B. juncea, and Sinapis alba (0.5 to 2.0\%) for the suppression of weeds (2); Phytophthora rubi and Pratylenchus penetrans (12); and Pythium spp. and P. penetrans (17). In our study, the soil amendment rates tested equate to field amendment rates of $10 \mathrm{t} / \mathrm{ha}$ for $0.5 / 1.0 \mathrm{MSM}+\mathrm{MS}$ and $20 \mathrm{t} / \mathrm{ha}$ for $1.0 / 1.0$ MSM+MS. At these rates, there is also the potential for MSM+MS to be phytotoxic to the plant species evaluated in this study, indicating that caution is warranted when establishing plants in soil

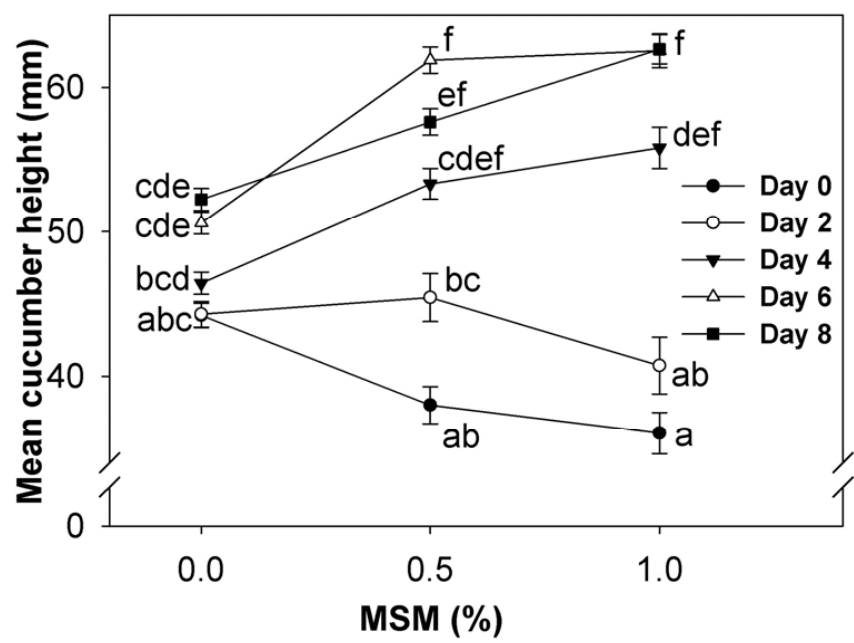

Fig. 3. Height response of cucumber (10 seeds/pot) planted into soil at 0-, 2-, 4-, 6-, and 8-day intervals after amendment with $0.0,0.5$, or $1.0 \%$ (wt/wt) meadowfoam seed meal (MSM) formulated with $1 \%(\mathrm{wt} / \mathrm{wt})$ meadowfoam seed (MS) under ambient greenhouse conditions ( 23 and $18^{\circ} \mathrm{C}$, day and night, respectively); $n=10$ replicate pots. MSM-day treatment means followed by the same letter are not significantly different according to Tukey's test at $P=0.05$. Error bars indicate standard error. treated with MSM+MS, and delayed planting after amendment might be required. In our assay for glucolimnanthin degradation compounds produced in MSM+MS-amended soils, ITC was the most likely compound responsible for pathogen and nematode mortality, given that most mortality occurred within $2 \mathrm{~h}$ after amending soil with MSM+MS during the period of time that concentrations of this compound were increasing rapidly.

Because of the inactivation of myrosinase by heat during the oil extraction process (26), there is a unique opportunity to direct the production of glucolimnanthin degradation products from MSM. The addition of enzyme-active MS to MSM results in complete degradation of glucolimnanthin and formation of ITC and nitrile, while incubation of MSM and MS in an aqueous solution of $\mathrm{FeSO}_{4}$ favors the formation of ITC, nitrile, and thioamide (26). Because we previously observed that ITC was the glucolimnanthin degradation product most toxic to M. hapla and Pythium irregulare (33), we chose to forgo the inclusion of $\mathrm{FeSO}_{4}$ and combine MSM solely with MS to promote ITC production. The lowest tested MS formulation evaluated $(1.0 \%)$ was more than enough to stimulate the glucolimnanthin degradation pathway; whether even lower formulations of MS would achieve a similar effect is not known.

When MSM was applied to soil alone, there was a significant reduction in $M$. hapla survival but a significant increase in population densities of $P$. irregulare. ITC concentrations are almost undetectable in MSM alone $(0.19 \mu \mathrm{mol} / \mathrm{g}$ of MSM, which would correspond to $9.5 \times 10^{-4}$ and $1.9 \times 10^{-3} \mu \mathrm{mol} / \mathrm{g}$ of soil at the 0.5 and $1.0 \%$ amendment rates, respectively) because of the lack of myrosinase in the system $(26,27)$. Therefore, ITC would not be responsible for the suppression of M. hapla observed in soils
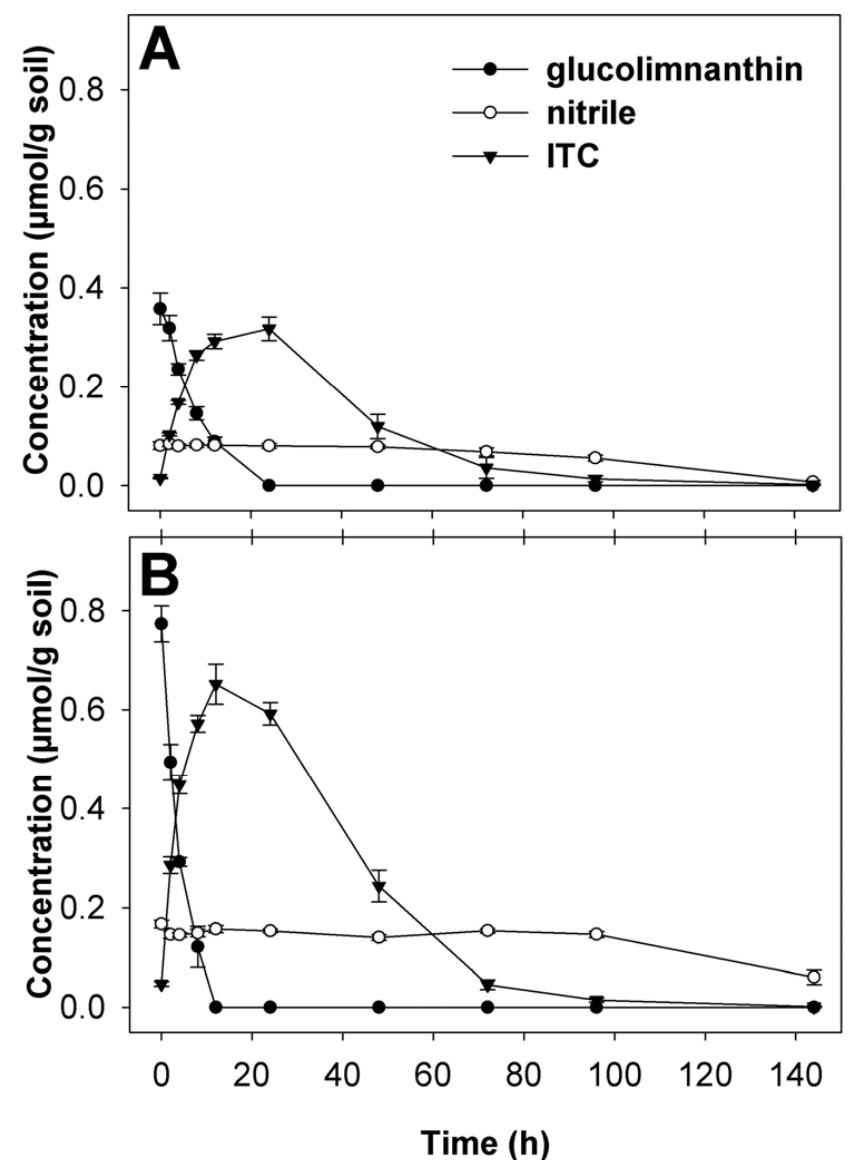

Fig. 4. Concentrations of glucolimnanthin, 3-methoxyphenylacetonitrile (nitrile), and 3-methoxybenzyl isothiocyanate (ITC) at 0, 2, 4, 8, 12, 24, 48, 72, 96, and $144 \mathrm{~h}$ after soil amendment with $\mathbf{A}, 0.5 \%$ (wt/wt) meadowfoam seed meal formulated with $1.0 \%$ meadowfoam seed or $\mathbf{B}, 1.0 \%$ (wt/wt) meadowfoam seed meal formulated with $1.0 \%$ meadowfoam seed at $20^{\circ} \mathrm{C} ; n=$ six replicate extractions. Error bars indicate standard error. 
amended only with MSM. However, MSM alone does contain nitrile $(18.3 \mu \mathrm{mol} / \mathrm{g}$ of MSM, which would correspond to 0.092 and $0.1 .80 \mathrm{umol} / \mathrm{g}$ of soil at the 0.5 and 1.0 amendment rates, respectively) (27), which also exhibited nematicidal activity (33). Although we did not measure nitrile concentrations in soils amended only with MSM, M. hapla in soils amended with $0.5 / 1.0$ and 1.0/1.0 MSM+MS were exposed to maximum concentrations of nitrile of $0.077 \mathrm{mg} / \mathrm{ml}$ and $0.147 \mathrm{mg} / \mathrm{ml}$ (as converted from $\mu \mathrm{mol}$ nitrile/g of soil). In our previous study, the concentration of nitrile needed to cause $50 \%$ mortality of M. hapla after a 24-h exposure was $0.1 \mathrm{mg} / \mathrm{ml}$; however, $40 \%$ mortality of $M$. hapla occurred in aqueous assays at nitrile concentrations as low as 0.05 $\mathrm{mg} / \mathrm{ml}$ (33). Therefore, it is possible that at least some of the $M$. hapla mortality observed in soil amended with MSM alone was due to toxic concentrations of nitrile. The complete opposite response to that of $M$. hapla was observed for $P$. irregulare when MSM was added to soil alone; a 25-fold increase in $P$. irregulare populations occurred regardless of the amendment rate. In our previous study, the concentration of nitrile needed to cause $50 \%$ mortality of $P$. irregulare after a 24-h exposure was $0.9 \mathrm{mg} / \mathrm{ml} \mathrm{(33),}$ which was much higher than the concentrations found in this study at the 0.5/1.0 and 1.0/1.0 MSM+MS amendment rates (nitrile at 0.077 and $0.147 \mathrm{mg} / \mathrm{ml}$, respectively). In addition, $P$. irregulare is a facultative saprophyte and has the ability to survive and increase in the presences of organic substrates (28). Others have also observed an increase in Pythium spp. populations in soils amended with brassicaceous seed meals. For example, Pythium spp. populations significantly increased in soil amended with $B$. napus seed meal flakes (7) and $P$. irregulare populations increased in abundance compared with other Pythium spp. in soils amended with $B$. juncea (17). These observations led to the conclusion that certain brassicaceous amendments may actually exacerbate disease severity (17). Based on our study, it appears that this would also be true if MSM was applied alone to P. irregulare-infested soil.

It has been demonstrated that MSM has herbicidal properties; therefore, the phytotoxicity observed here is not unexpected. MSM+MS had increased herbicidal potency compared with MSM alone, resulting in decreased downy brome (Bromus tectorum) coleoptile emergence (27). The glucolimnanthin degradation compound nitrile was implicated as the active compound causing herbicidal activity in ethyl ether and ethanol extracts of MSM (29). In this study, therefore, it is likely that nitrile played a role in wilt of tomato transplants and decreased germination and height of directseeded cucumber and wheat when MSM was applied alone at rates of $1.0 \%$ or greater. As stated above, nitrile is the only toxic compound that would be present in significant quantities in MSMamended soil. Impacts on seed germination and plant growth were further exacerbated when MS was added to MSM, indicating that ITC also contributed to herbicidal activity.

Although it is clear that MSM+MS can be an effective herbicide, the goal in this study was to understand the management components necessary to apply MSM+MS to suppress $P$. irregulare and M. hapla. Our data clearly demonstrate that planting tomato, cucumber, and wheat will have to be delayed after MSM+MS is amended to soil. Our data indicate that this period of time may need to be longer when transplants are used instead of crops that are direct seeded. For example, 2-week-old sprouted onion plants were injured up to 8 weeks after amending soil with $S$. alba seed meal (3), which resulted in a $29 \%$ reduction in onion size in 1 year of the study. The necessity for delayed planting after the incorporation of brassicaceous seed meals into soil has also been reported for carrot (15 to 36 days) (23) and strawberry (14 days) (1). Environmental conditions at soil amendment and planting can also play a role in phytotoxicity and duration of the phytotoxic effect, something that was not considered in this study. One strategy that could be used to avoid crop phytotoxicity by MSM+MS would be to amend soil in the fall and then plant the crop in the following spring. For M. hapla, this would also be ideal because juvenile populations in soil are greater in the fall than in the spring (I. A. Zasada, unpublished data).
A significant fertilizer effect was also observed in these experiments. When cucumber was seeded into soils amended with MSM+MS 6 to 8 days earlier (with the exception of seed planted into soils at the $0.5 \%$ amendment rate 6 days earlier), the plants were taller at the end of the experiment compared with those grown in nonamended soil. Similar observations have been made with other brassicaceous seed meals. In carrot, for example, crop quality was unaffected by a delayed planting into soils amended with Brassica napus, B. juncea, or $S$. alba seed meals and, in some cases, carrot yields were greater in amended soils than in the nonamended control (23). Similarly, strawberry fruit yield increased in the first growing season after amending field soils with $S$. alba and $B$. napus seed meal at $4.5 \mathrm{t} / \mathrm{ha}$ (1). Brassicaceous seed meals contain 5 to $6 \% \mathrm{~N}$ by weight and have $\mathrm{C} / \mathrm{N}$ ratios of approximately $8: 1$ (11). In laboratory incubation assays of soil amended with $B$. $n a$ pus, B. juncea, or S. alba, 41 to $46 \%$ of the mineralized seed meal $\mathrm{N}$ was recovered in the inorganic pool after 15 days, making it a readily available source of $\mathrm{N}$ for plants (24). Depending on the treatment, the duration of our time-course phytotoxicity assay extended from 14 to 22 days, which would have been adequate time for $\mathrm{N}$ mineralization to occur. It would be expected that MSM would have characteristics similar to these other related seed meals and that the growth response of cucumber observed in this study was due to a greater availability of $\mathrm{N}$ being provided to the plant from the MSM.

In our assay, where glucolimnanthin degradation products in soil were monitored in relation to nematode and pathogen suppression, $P$. irregulare and $M$. hapla were completely killed within $2 \mathrm{~h}$ after amending soil with MSM+MS. This was likely due to the activity of ITC rather than nitrile. At $2 \mathrm{~h}$ after amendment, ITC at an average of 0.12 and $0.28 \mathrm{mg} / \mathrm{ml}$ and nitrile at 0.077 and $0.147 \mathrm{mg} / \mathrm{ml}$ were recovered from soil amended with 0.5/1.0 MSM+MS and 1.0/1.0 MSM+MS, respectively. In our previous study (33), we estimated that ITC at $0.005 \mathrm{mg} / \mathrm{ml}$ and nitrile at $0.5 \mathrm{mg} / \mathrm{ml}$ were required to cause $100 \%$ mortality of $M$. hapla in an aqueous solution; this concentration of ITC was achieved in soil immediately after amendment with 0.5/1.0 MSM+MS, whereas the concentration of nitrile necessary to kill M. hapla was not achieved in soil. These results indicate that ITC was the primary glucolimnanthin degradation product responsible for the mortality of M. hapla. In contrast, $P$. irregulare was not completely killed in our previous study, even with the highest concentrations of ITC $(0.2 \mathrm{mg} / \mathrm{ml})$ and nitrile $(1.0 \mathrm{mg} / \mathrm{ml})$; only 88 and $71 \%$ mortality was observed with each compound, respectively (33). Regardless of the amendment rate used in the present study, the $1.0 \mathrm{mg} / \mathrm{ml}$ concentration of nitrile required to kill $71 \%$ of $P$. irregulare was not achieved. However, within $2 \mathrm{~h}$ after incorporating the 1.0/1.0 MSM+MS amendment, the concentration of ITC was $0.28 \mathrm{mg} / \mathrm{ml}$, which exceeded the highest concentration of ITC tested in our previous study. Concentrations of ITC continued to rise thereafter until they peaked at $24 \mathrm{~h}$ at $0.71 \mathrm{mg} / \mathrm{ml}$. Therefore, the results also indicate that ITC was the primary glucolimnanthin degradation product responsible for the mortality of $P$. irregulare.

Our research indicates the potential of MSM formulated with MS as a soil amendment to control M. hapla and P. irregulare. The soil amendment rates determined to cause complete mortality of $M$. hapla and P. irregulare (0.5/1.0 MSM + MS and 1.0/1.0 MSM + MS, respectively) are achievable in the field but a delayed planting of crops into amended soils will be necessary to prevent unintended crop phytotoxicity. However, once the toxic glucolimnanthin degradation products have dissipated, the remaining MSM product also has a fertilizer effect, making it a dual-use product. As we found in our previous study, both target organisms were the most sensitive to ITC, which was produced rapidly and peaked within $24 \mathrm{~h}$ after MSM+MS amendment into soil. However, the complete mortality of $P$. irregulare observed in the study could not be explained by the concentration of either ITC or nitrile alone; the dose of each compound that the $P$. irregulare was exposed to should have been incompletely lethal according to our previous study. Therefore, future experiments should consider evaluating the 
combined effects of nitrile and ITC on nematode and plant pathogen suppression. This research has provided the foundation necessary to take the next step toward the implementation of MSM into crop production systems; namely, the integration and evaluation of MSM as a disease management strategy in assays combining both a plant host and plant pathogen or plant-parasitic nematode.

\section{Acknowledgments}

Funding for this project was provided by the Republic of Turkey Council of Higher Education and United States Department of Agriculture CRIS 303-535812220-003-00D. We thank Natural Plant Products, Inc., Salem, OR for meadowfoam seed and seed meal; and A. Davis, B. Beck, D. Kroese, S. Intanon, and A. Peetz for technical assistance.

\section{Literature Cited}

1. Bañuelos, G. S., and Hanson, B. D. 2010. Use of selenium-enriched mustard and canola seed meals as potential bioherbicides and green fertilizer in strawberry production. HortScience 45:1567-1572

2. Boydston, R. A., Anderson, T., and Vaughn, S. F. 2008. Mustard (Sinapis alba) seed meal suppresses weeds in container-grown ornamentals. HortScience 43:800-803.

3. Boydston, R. A., Morra, M. J., Borek, V., Clayton, L., and Vaughn, S. F. 2011. Onion and weed response to mustard (Sinapis alba) seed meal. Weed Sci. 59:546-552.

4. Brown, P. D., and Morra, M. J. 1995. Glucosinolate-containing plant tissues as bioherbicides. J. Agric. Food Chem. 43:3070-3074.

5. Brown, P. D., and Morra, M. J. 1997. Control of soil-borne plant pests using glucosinolate-containing plants. Adv. Agron. 61:167-231.

6. Chitwood, D. J. 2002. Phytochemical based strategies for nematode control. Annu. Rev. Phytopathol. 40:221-249.

7. Cohen, M. F., and Mazzola, M. 2006. Resident bacteria, nitric oxide emission and particle size modulate the effect of Brassica napus seed meal on disease incited by Rhizoctonia solani and Pythium spp. Plant Soil 286:7586.

8. Fahey, J. W., Zalcmann, A. T., and Talalay, P. 2001. The chemical diversity and distribution of glucosinolates and isothiocyanates among plants. Phytochemistry $56: 5-51$

9. Farr, D. F., Bills, G. F., Chamuris, G. P., and Rossman, A. Y. 1989. Fungi on Plants and Plant Products in the United States. American Phytopathological Society, St. Paul, MN.

10. Franklin, M. T. 1979. Economic importance of Meloidogyne in temperate climates. Pages 331-340 in: Root-Knot Nematodes (Meloidogyne Species)—Systematics, Biology, and Control, F. Lamberti and C. E. Taylor, eds. Academic Press, New York.

11. Gale, E. S., Sullivan, D. M., Cogger, C. G., Bary, A. I., Hemphill, D. D., and Myhre, E. A. 2006. Estimating plant-available nitrogen release from manures, composts, and specialty products. J. Environ. Qual. 35:2321-2332.

12. Gigot, J. A., Zasada, I. A., and Walters, T. W. 2013. Integration of brassicaceous seed meals into red raspberry production systems. Appl. Soil Ecol. 64:23-31

13. Ingham, R. E. 1994. Nematodes. Pages $459-490$ in: Methods of Soil Analysis. Part 2, Microbiological and Biochemical Properties. R. W. Weaver, J. S. Angle, and P. S. Bottomley, eds. Soil Science Society of America, Inc., Madison, WI.

14. Kannwischer, M. E., and Mitchell, D. J. 1978. The influence of a fungicide on the epidemiology of black shank of tobacco. Phytopathology 68:17601765 .

15. Kirkegaard, J. A., and Sarwar, M. 1998. Biofumigation potential of brassi- cas: Variation in glucosinolate profiles of diverse field-grown brassicas. Plant Soil 201:71-89.

16. Linderman, R. G., and Zeitoun, F. 1977. Phytophthora cinnamomi causing root rot and wilt of nursery-grown native western azalea and salal. Plant Dis. Rep. 61:1045-1048

17. Mazzola, M., Brown, J., Zhao, X. W., Izzo, A. D., and Fazio, G. 2009. Interaction of brassicaceous seed meal and apple rootstock on recovery of Pythium spp. and Pratylenchus penetrans from roots grown in replant soils. Plant Dis. 93:51-57.

18. Miller, R. W., Daxenbichler, M. E., and Earle, F. R. 1964. Search for new industrial oils. VIII. The genus Limnanthes. J. Am. Oil Chem. Soc. 41:167 169.

19. Mojtahedi, H., Santo, G. S., Hang, A. N., and Wilson, J. H. 1991. Suppression of root-knot nematode populations with selected rapeseed cultivars as green manure. J. Nematol. 23:176-174.

20. Mojtahedi, H., Santo, G. S., Wilson, J. H., and Hang, A. N. 1993. Managing Meloidogyne chitwoodi on potato with rapeseed as green manure. Plant Dis. $77: 42-46$

21. Sarwar, M., Kirkegaard, J. A., Wong, P. T. W., and Desmarchelier, J. M. 1998. Biofumigation potential of brassicas: III. In vitro toxicity of isothiocyanates to soil-borne fungal pathogens. Plant Soil 201:103-112.

22. Shah, D. A., and Madden, L. V. 2004. Nonparametric analysis of ordinal data in designed factorial experiments. Phytopathology 94:33-43.

23. Snyder, A., Morra, M. J., Johnson-Maynard, J., and Thill, D. C. 2009. Seed meals from Brassicaceae oilseed crops as soil amendments: Influence on carrot growth, microbial biomass nitrogen, and nitrogen mineralization. HortScience 44:354-361.

24. Snyder, A. J., Johnson-Maynard, J. L., and Morra, M. J. 2010. Nitrogen mineralization in soil incubated with $15 \mathrm{~N}$-labeled Brassicaceae seed meals. Appl. Soil Ecol. 46:73-80.

25. Sokal, R. R., and Rohlf, F. J. 2012. Biometry, Fourth Edition. W. H. Freeman and Company, New York.

26. Stevens, J. F., and Reed, R. L. 2011. Glucosinolate degradation products in fermented meadowfoam seed meal and their herbicidal activities. Pages 141-158 in: The Biological Activity of Phytochemicals. D. R. Gang, ed. Springer, New York.

27. Stevens, J. F., Reed, R. L., Alber, S., Pritchett, L., and Machado, S. 2009. Herbicidal activity of glucosinolate degradation products in fermented meadowfoam (Limnanthes alba) seed meal. J. Agric. Food Chem. 57:1821 1826

28. van der Plaats-Niterink, A. J. 1981. Monograph of the genus Pythium. Stud. Mycol. 21:1-242.

29. Vaughn, S. F., Boydston, R. A., and Mallory-Smith, C. A. 1996. Isolation and identification of (3-methoxyphenyl)acetonitrile as a phytotoxin from meadowfoam (Limnanthes alba) seedmeal. J. Chem. Ecol. 22:1939-1949.

30. Weiland, J. E. 2011. Influence of isolation method on recovery of Pythium species from forest nursery soils in Oregon and Washington. Plant Dis. 95:547-553.

31. Weiland, J. E., Beck, B. R., and Davis, A. 2013. Pathogenicity and virulence of Pythium species obtained from forest nursery soils on Douglas-fir seedlings. Plant Dis. 97:744-748.

32. Weiland, J. E., Leon, A. L., Edmonds, R. L., Littke, W. R., Browning, J. E., Davis, A., Beck, B. R., Miller, T. W., Cherry, M. L., and Rose, R. 2011. The effects of methyl bromide alternatives on soil and seedling pathogen populations, weeds, and seedling morphology in Oregon and Washington forest nurseries. Can. J. For. Res. 41:1885-1896.

33. Zasada, I. A., Weiland, J. E., Reed, R. L., and Stevens, J. F. 2012. Activity of meadowfoam (Limnanthes alba) seed meal glucolimnanthin degradation products against soilborne pathogens. J. Agric. Food Chem. 60:339-345. 